\title{
우리나라의 개발협력 자체평가 품질강화를 위한 메타평가 추진방안
}

현 미 주 (외교통상부 개발정책과 2등서기관)

\section{목 차}

1. 도입

2. 자체평가 품질 관리의 중요성

3. 2010-2011년 자체평가 품질에 대한 메타평가 결과

4. 향후 효과적인 메타평가 추진을 위한 제언

\section{1. 도입}

2012년 말 개최된 제11차 국제개발평가소위원회는 2014년부터 2년 주기로 자체평가 결과보 고서에 대한 메타평가를 실시하기로 의결하였다. 메타평가란 간단히 말해서 평가 품질을 확보 하기 위해 평가에 대해 실시하는 평가, 즉 평가에 대한 평가이다. 동 메타평가 제도의 도입으 로 우리나라 국제개발협력 평가, 특히 자체평가 제도가 보다 내실화될 수 있을 것으로 기대된 다. 동 기고문에서는 정부가 왜 이러한 제도를 도입하게 되었는지를 살펴보고, 시범 메타평가 결과를 바탕으로 현 시점에서의 자체평가의 문제점과 향후 발전방향을 검토해 보고자 한다.

(우리나라 국제개발협력 평가제도 개요)

메타평가에 대한 논의에 앞서, 현재 우리나라의 국제개발협력 평가제도를 간략히 살펴볼 필 
요가 있다. 2009년까지 우리나라는 ODA 사업을 시행하는 기관별로 상이한 기준과 지침을 가 지고 자체평가를 실시하였으나, ‘국제개발협력기본법’이 시행되는 2010년부터 모든 ODA 사업 에 공통적인 평가 원칙, 기준 및 절차를 적용하는 ‘통합평가 시스템’을 도입하였다. 동 통합평 가 시스템은 크게 평가소위원회가 추진하는 '소위평가'와 ODA 시행기관이 자체 추진하는 '자 체평가'로 이루어지며, 2010년 이래 매년 3건의 소위평가, 약 20여건의 자체평가가 실시되고 있다. ${ }^{1)}$

\section{〈그림 1 : 통합평가 흐름도〉}

\begin{tabular}{|c|c|}
\hline 자체평가 & 소위평가 \\
\hline 각 시행기관, 자체평가 계획(안) 제출 & 평가협조기관, 소위평가 계획(안)에 대한 의견 제출 \\
\hline 평가 헙조기관, & \\
유상별 평가계획 최종 취합 및제출 & 평가소위원회, 소위평가 계획 심의 \\
\hline 평가 소위원회, 연간 동합평가 계획 심의 &
\end{tabular}

국제개발협력위원회, 연간 통합평가 계획 확정

\section{국제개발헙력위원회, 연간 통합평가 계획 확정}

각 시행기관, 평가 이행 및 결과 보고

$$
\text { 평가 이행 }
$$

평가 헙조기관, 평가 결과 취합 및 총평 작성·보고

평가소위원회, 평가 결과 심의

국제개발헙력위원회 평가 결과 확정 및 연간시행계획에 반영

평가 결과에 따른 후속조치 이행
평가소위원회, 평가 결과 심의

국제개발협력위원회 평가 결과 확정

1) 국제개발협력 통합평가제도에 대한 자세한 사항은 외교통상부 개발협력 홈페이지(www.devkorea.go.kr) 우리나라 $\mathrm{ODA}$ 체계- 개발협력정책 및 전략-개발협력평가를 참고 
이와 관련, 외교통상부는 '국제개발협력법’ 제9조상 무상원조 주관기관이자 '평가소위원회 운영규정’ 제 13 조상 평가 협조기관으로서, 각 부처 등 무상원조 시행기관들의 평가 계획 수립 및 결과를 종합하여 평가소위원회에 상정하고, 환류조치 이행을 지원하고 있다.

\section{2. 자체평가 품질관리의 중요성 : 왜 메타평가를 도입해야 하는가}

메타평가 도입은 2012년 초 제10차 평가소위원회에서 외교통상부가 메타평가 시범 시행 및 메타평가 제도 구축을 제안하면서 비롯되었다. 당시 외교통상부는 자체평가 보고서 품질개선 이 시급한 과제라는 점을 지적하였으며, 평가소위 간사기관인 국무총리실 역시 이러한 문제의 식을 공유하면서 평가소위 위원들의 의결을 거쳐 메타평가가 2012년 소위평가 계획에 포함되 었다.

외교통상부는 한국국제협력단(KOICA)과 같은 원조 전담기관뿐만 아니라 기획재정부, 보건 복지부, 교육과학기술부, 농림수산식품부 등과 같이 무상원조 사업을 시행하는 기관들의 자체 평가 결과보고서 검토 및 이들 기관과의 자체평가에 대한 협의 등의 업무를 수행해왔기 때문 에 통합평가 시스템 출범 이후 자체평가 제도의 문제점을 지속 파악하고 있었다.

외교통상부가 언급한 현 자체평가 제도의 문제점은 다음과 같았다. 우선, 원조전담기관을 제외한 여타 부처의 경우, 국제개발협력 평가에 대한 이해와 역량이 부족하여 통합평가지침만 으로는 양질의 자체평가 결과보고서를 도출하기 어렵다는 점이다.

사실 통합평가체제가 출범한 지 얼마되지 않은 상황에서 그간 개발협력 관점이 없이 국제협 력 또는 경제협력 차원에서 사업을 추진해 온 여러 시행기관(KOICA 제외) 입장에서는 통합평 가지침에서 언급하는 기준(적절성, 효율성, 효과성, 영향력, 지속가능성)을 바로 이해하고 적 용하기 쉽지 않았다. 이러한 사유로 많은 보고서들이 사후적으로 상기 기준에 끼워 맞춘 경향 이 적지 않았다. 또한 양질의 평가를 위해서는 적절한 평가지표 마련, 현장에서의 기초조사 등 평가 설계가 미리 이루어져야 하는데, 이를 위해서는 상당한 평가인프라(예산 및 전문인력 등) 가 필요했으며 지금과 같이 분절화된 무상원조 체계에서 다양한 기관들이 소규모의 사업을 추 진하는 경우에는 평가를 중점적으로 추진하기 어렵다는 보다 근본적인 문제도 존재했다. 실제 로 많은 기관들이 평가를 추진하는데 있어, 현실적인 어려움을 표명했으며, 자체평가 대상이 
되는 것을 기피하였다. 또한 $\mathrm{ODA}$ 사업 예산이 크지 않은 기관들은 통합평가지침의 존재를 인 식하지 못하는 경우도 있었다. 결과적으로, 원조전담기관(KOICA 및 $\mathrm{EDCF})$ 와 여타 시행기관 간의 자체평가 보고서의 수준 차이는 상당했으며, 후자의 결과보고서는 국제개발협력분야에서 공개하여 사용할 수 있는 평가 보고서라고 간주하기에는 미흡한 수준이었던 것이다.

둘째, 여타 시행기관의 자체평가의 경우 유의미한 평가결과를 담고 있지 않기 때문에 보다 더 효과적인 개발협력 사업을 위한 환류(feedback)가 가능하지 않았으며, 이로 인해 자체평가 의 본래의 목적을 달성할 수 없었다. 자체평가 결과보고서가 의미가 있기 위해서는 자체평가 결과로부터 얻은 '교훈'을 해당 사업 또는 이후 여사한 사업 추진에 있어 적용할 수 있어야 하 는데 품질이 낮은 평가는 추상적이고 모호한거나 잘못된 결과를 도출하기 쉽기 대문에 현실적 인 교훈 도출과 적용이 어렵기 때문이다.

사실 원조전담기관을 제외한 여타 시행기관의 경우에 국제개발협력 사업의 선진화 필요성 이 더 크고, 이를 위해 정확한 평가에 따른 개선작업이 긴요함에도 불구하고 미흡한 평가로 인 한 환류 부족으로 $\mathrm{ODA}$ 사업의 수준이 제자리 걸음하는 결과를 초래하는 문제가 있다.

메타평가를 도입해야 하는 이유는 이러한 문제점 때문이다. 자체평가 제도가 양질의 자체평 가 결과보고서를 도출하지 못한다면, 평가제도의 의미가 없어진다. 때문에 자체평가와 "품질 관리(quality assurance)"는 분리하여 생각할 수 없으며, 자체평가의 품질관리 장치로써 메타 평가는 필요하다. "평가가 제대로 이루어지는가? 평가결과가 유의미한가? 어떻게 해야 보다 정확한 평가결과를 도출할 수 있는가?”라는 질문을 함으로써, 품질이 높은 평가보고서를 도출 하기 위한 작업을 지속해야만 평가 결과를 의미있게 ODA 사업에 반영하여 효과성이 높은 사 업으로 개선할 수 있다.

특히 지금과 같이 분절화된 무상원조 체계에서는 원조전담기관을 제외한 여타 시행기관이 품질관리를 스스로 추진하기 어렵기 때문에 평가소위원회 및 국제개발협력위원회 차원에서 ‘품질관리’에 대한 유인(incentive) 체계를 마련하여 보다 양질의 평가결과 보고서를 도출할 수 있도록 제도적으로 지원해 줄 필요가 있다. 물론 장기적으로 원조전담기관으로 통합되어 일원화된 무상원조 체계가 구축된다면, 자체평가 품질관리가 훨씬 더 효과적으로 이루어질 수 있겠지만, 현 체제는 일원화가 되지 않은 상황이므로 이에 맞는 제도적 보완 방안을 구축하는 것이 현실적이라고 여겨진다. 


\section{2010-2011년 자체평가 품질에 대한 메타평가 결과}

상기 자체평가 품질관리의 중요성을 감안하여, '2010년 및 2011년 자체평가에 대한 메타평 가'는 2012년 평가소위원회 소위평가 과제로서 시범 추진되었다. 한국개발전략연구원(Korea Institute for Development Strategy: KDS)은 동 과제 수행기관으로서, 자체평가 결과보고 서 품질에 대한 시범적인 평가를 시행하여 현 상황을 점검하고 모범사례를 도출하였으며, 메 타평가를 추진하기 위해 마련되어야 할 체크리스트(안) 등 평가 도구를 모색하기 위한 기초자 료를 제공하였다. 자세한 내용은 '2010년-2011년 자체평가 품질에 대한 메타평가’제하의 용역 보고서(이하 메타평가 결과보고서)' 및 제11차 국제개발협력 평가소위원회 안건(ODA 시행기 관의 자체평가에 대한 메타평가 결과)을 참고바란다. 금번 메타평가 결과보고서는 평가시스 템, 평가과정, 평가보고서의 3 가지 측면에 대해 모두 검토하였으나, 이하에서는 동 보고서 내 용 중 일부인 평가보고서에 대한 메타평가 결과를 중점적으로 설명하고, 동 메타평가 결과가 주는 함의를 살펴보고자 한다.

금번 메타평가는 아래의 분석틀을 기준으로 2010년 및 2011년 자체평가 보고서 총 38건 중 평가기관, 분야 등을 고려하여 17 개를 표본으로 추출한 뒤 이루어졌으며, 평가항목별로 등급 화하고 그 개선방안을 제시하였다.

〈표1〉메타평가 분석틀

\begin{tabular}{|c|c|c|c|}
\hline 구분 & 평가 시스템 & 평가 과정 & 평가 보고서 \\
\hline $\begin{array}{l}\text { 평가 } \\
\text { 항목 }\end{array}$ & $\begin{array}{l}\text { O 평가정책 분석 } \\
\text { - 평가정책 } \\
\text { - 평가계획 } \\
\\
\text { 평가자원 분석 } \\
\text { - 평가예산 } \\
\text { - 평가조직 } \\
\text { - 평가인력 }\end{array}$ & $\begin{array}{l}\text { 응ㄱ아용역 수행의 적절성 } \\
\text { - 용역제안서 } \\
\text { - 평가팀 구성 } \\
\text { - 용역지원 } \\
\text { - 품질관리 } \\
\text { 평가수행의 } \\
\text { 독립성·자율성 } \\
\text { - 독립성 } \\
\text { - 자율성 }\end{array}$ & $\begin{array}{l}\text { O 보고서 충실성 분석 } \\
\text { - 평가배경·목적 } \\
\text { - 평가대상 } \\
\text { - 평가방법 · 디자인 } \\
\text { O DAC 5대 평가기준 } \\
\text { - 적절성 } \\
\text { - 효과성 } \\
\text { - 효율성 } \\
\text { - 영향력 } \\
\text { - 지속가능성 }\end{array}$ \\
\hline
\end{tabular}




\begin{tabular}{|c|c|c|c|}
\hline 구분 & 평가 시스템 & 평가 과정 & 평가 보고서 \\
\hline & $\begin{array}{l}\text { 영가결과 } \\
\text { 확산 - 환류 분석 } \\
\text { - 평가확산 } \\
\text { - 평가환류 }\end{array}$ & $\begin{array}{l}\text { 이히해관계자 참여·보호 } \\
\text { - 참 여 } \\
\text { - 보 호 }\end{array}$ & $\begin{array}{l}\text { O 보고서 논리성 분석 } \\
\text { - 자료의 신뢰성 } \\
\text { - 분석의 명확성 } \\
\text { - 결론의 타당성 } \\
\text { - 제언의 유용성 } \\
\text { 이타사항 분석 } \\
\text { - 범분야 이슈 } \\
\text { - 보고서 명료성 }\end{array}$ \\
\hline $\begin{array}{l}\text { 평가 } \\
\text { 방법 }\end{array}$ & $\begin{array}{l}\text { - 기관별 설문조사 } \\
\text { - 평가부서 인터뷰 }\end{array}$ & $\begin{array}{l}\text { - 용역제안서 검토 } \\
\text { - 기관별 설문조사 } \\
\text { - 평가자 - 평가담당자 인터뷰 }\end{array}$ & - 보고서 검토 \\
\hline
\end{tabular}

〈표 2〉메타평가 결과 종합

\begin{tabular}{|c|c|c|c|c|}
\hline $\begin{array}{l}\text { 평가 } \\
\text { 요소 }\end{array}$ & 항 목 & 세부항목 & 평가결과 & 개선방향 \\
\hline \multirow{7}{*}{$\begin{array}{l}\text { 평 } \\
\text { 가 } \\
\text { 시 } \\
\text { 스 } \\
\text { 템 }\end{array}$} & \multirow{2}{*}{$\begin{array}{l}\text { 평가 } \\
\text { 정책 }\end{array}$} & 평가정책 & - 대부분 기관이 평가정책 불명확 & - 내부 사업평가 지침 마련 필요 \\
\hline & & 평가계획 & - 계획 수립을 위한 평가위원회 운영 미흡 & - 기관별 평가위원회 운영 확대 필요 \\
\hline & \multirow{3}{*}{$\begin{array}{l}\text { 평가 } \\
\text { 자원 }\end{array}$} & 평가예산 & $\begin{array}{l}\text { 일부 기관의 평가예산 비중이 DAC 최소 } \\
\text { 비율인 } 0.02 \% \text { 에 미달 }\end{array}$ & $\begin{array}{l}\text { 평가예산 확보 노력, 평가예산 배분시 } \\
\text { 선택과 집중 필요 }\end{array}$ \\
\hline & & 평가조직 & - KOICA · EDCF에만 별도 평가부서 존재 & $\begin{array}{l}\text { - 고도의 객관성이 요구되는 평가는 평가 } \\
\text { 소위에서 통합평가 실시 필요 }\end{array}$ \\
\hline & & 평가인력 & - 부처의 경우, ODA 평가인력 및 전문성 부족 & - ODA 평가교육 확대 필요 \\
\hline & \multirow{2}{*}{$\begin{array}{l}\text { 평가 } \\
\text { 활용 }\end{array}$} & 평가확산 & $\begin{array}{l}\text { - 대부분 기관이 평가보고서를 수원국에 } \\
\text { 배포 }\end{array}$ & • 평가보고서를 국제사회와 공유 필요 \\
\hline & & 평가환류 & • 정책제언 이행의 구속력 · 인센티브 미흡 & $\begin{array}{l}\text { - 구속력 확보·인센티브 부여방안 검토 } \\
\text { 필요 }\end{array}$ \\
\hline \multirow{4}{*}{$\begin{array}{l}\text { 평 } \\
\text { 가 } \\
\text { 과 } \\
\text { 정 }\end{array}$} & \multirow{4}{*}{$\begin{array}{l}\text { 평가 } \\
\text { 용역 } \\
\text { 적절성 }\end{array}$} & $\begin{array}{l}\text { 용역 } \\
\text { 제안서 }\end{array}$ & •구체성 부족, 평가배경 언급 미흡 & $\begin{array}{l}\text { - 평가질문 · 평가수행 방향 명확히 제시 } \\
\text { 필요 }\end{array}$ \\
\hline & & $\begin{array}{l}\text { 평가 } \\
\text { 팀구성 }\end{array}$ & $\begin{array}{l}\text { - 사업분야별 전문가 위주로 평가팀이 구성 } \\
\text { 되어 전문성에 한계 노출 }\end{array}$ & • ODA 평가에 적합한 전문가 등급마련 필요 \\
\hline & & $\begin{array}{l}\text { 평가팀 } \\
\text { 지원 }\end{array}$ & $\begin{array}{l}\text { - 대체로 평가팀에 필요한 자료를 적기에 } \\
\text { 제공 }\end{array}$ & • 지원범위 명확화 및 정례회의 활성화 필요 \\
\hline & & 품질관리 & •구체적인 품질체크리스트 부재 & $\begin{array}{l}\text { - 품질관리를 위한 품질체크리스트 마련 } \\
\text { 필요 }\end{array}$ \\
\hline
\end{tabular}




\begin{tabular}{|c|c|c|c|c|}
\hline $\begin{array}{l}\text { 평가 } \\
\text { 요소 }\end{array}$ & 항 목 & 세부항목 & 평가결과 & 개선방향 \\
\hline & \multirow{2}{*}{\begin{tabular}{|l} 
평가독 \\
립성- \\
자율성
\end{tabular}} & 독립성 & $\begin{array}{l}\text { - 평가외부자가 평가 결과를 미리 결정 } \\
\text { 하고자 개입 }\end{array}$ & $\begin{array}{l}\text { - 독립성 강화를 위한 내부통제장치 마련 } \\
\text { 필요 }\end{array}$ \\
\hline & & 자율성 & $\begin{array}{l}\text { • 일부 기관에서 긍정적 결과만을 배포 } \\
\text { 하도록 압력 행사 }\end{array}$ & - 자율성 강화를 위한 내부지침 마련 필요 \\
\hline & \multirow{2}{*}{$\begin{array}{c}\text { 이해 } \\
\text { 관계자 } \\
\text { 참여· } \\
\text { 보호 }\end{array}$} & 참 여 & • 수원국의 참여는 다소 제한적임 & • 수원국 참여 수요 사전 논의 필요 \\
\hline & & 보 호 & - 이해관계자 보호를 위한 장치 부재 & $\begin{array}{l}\text { - 이해관계자 보호를 위한 내부지침 마련 } \\
\text { 필요 }\end{array}$ \\
\hline \multirow{14}{*}{$\begin{array}{l}\text { 평 } \\
\text { 가 } \\
\text { 보 } \\
\text { 고 } \\
\text { 서 }\end{array}$} & \multirow{3}{*}{$\begin{array}{c}\text { 보고서 } \\
\text { 의 } \\
\text { 충실성 }\end{array}$} & 배경·목적 & • 배경·목적이 일반적이거나 추상적 & - 배경 · 목적 · 평가질문 구체적 제시 필요 \\
\hline & & 평가대상 & -PDM에 대한 검토 미흡 & - 사업기획부터 명확한 PDM 수립 필요 \\
\hline & & 평가방법 & - 방법론에 대한 상세설명 불충분 & - 정교한 평가지표·메트릭스 제시 필요 \\
\hline & \multirow{5}{*}{$\begin{array}{c}\text { DAC } \\
5 \text { 대 } \\
\text { 기준 }\end{array}$} & 적절성 & - 직접 수혜자 및 수혜지역 특수성 분석 미흡 & $\begin{array}{l}\text { - 직접 수혜자 및 수혜지역 특수성 분석 강화 } \\
\text { 필요 }\end{array}$ \\
\hline & & 효과성 & - 목표가 명확하지 않아 달성정도 분석 미흡 & - 사업기획시 명확한 평가기준치 설정 필요 \\
\hline & & 효율성 & ·자원·비용 효율성 분석 미흡 & $\begin{array}{l}\text { - 자원 - 비용 효율성 분석 강화, 비효율성 } \\
\text { 지적시 원인 및 개선방안 함께 제시 }\end{array}$ \\
\hline & & 영향력 & $\begin{array}{l}\text { 의도하지 않은 영향력 및 간접 영향력 분석 } \\
\text { 미흡 }\end{array}$ & $\begin{array}{l}\text { - 사업계획시 달성하고자 하는 영향력 및 } \\
\text { 직·간접 수혜자를 분명하게 제시할 필요 }\end{array}$ \\
\hline & & $\begin{array}{c}\text { 지속 } \\
\text { 가능성 }\end{array}$ & - 지속가능성에 영향을 주는 요인 분석 미흡 & - 지속가능성의 영향요인에 대한 분석 강화 \\
\hline & \multirow{4}{*}{$\begin{array}{c}\text { 보고서 } \\
\text { 의 } \\
\text { 논리성 }\end{array}$} & $\begin{array}{l}\text { 자료의 } \\
\text { 신뢰성 }\end{array}$ & - 자료 수집방법에 대한 상세설명 부족 & • 자료 수집방법 명확히 제시할 필요 \\
\hline & & $\begin{array}{l}\text { 분석의 } \\
\text { 명확성 }\end{array}$ & $\begin{array}{l}\text { - 대체로 평가자의 주장이 객관적·논리적 } \\
\text { 으로 뒷받침되는 경향 }\end{array}$ & $\begin{array}{l}\text { • 평가설계시 평가지표와 측정방법간 논리 } \\
\text { 구조 확립 필요 }\end{array}$ \\
\hline & & $\begin{array}{l}\text { 결론의 } \\
\text { 타당성 }\end{array}$ & $\begin{array}{l}\text { - 대체로 평가결론이 평가의 주요 분석 } \\
\text { 내용과 유기적·논리적으로 연결 }\end{array}$ & $\begin{array}{l}\text { • 분석내용 및 국제사회 논의 등을 종합 고려 } \\
\text { 하여 균형잡힌 결론 제시 필요 }\end{array}$ \\
\hline & & $\begin{array}{l}\text { 제언의 } \\
\text { 유용성 }\end{array}$ & •실행가능한 행동계획 제시 미흡 & $\begin{array}{l}\text { - 실행가능한 행동계획을 이해관계자별로 } \\
\text { 우선순위를 부여하여 제시할 필요 }\end{array}$ \\
\hline & \multirow[b]{2}{*}{ 기 타 } & 범분야 & - 대부분 범분야 이슈 분석 누락 & - 사업계획시부터 범분야 이슈 고려 필요 \\
\hline & & 명료성 & $\begin{array}{l}\text { - 편집은 대체로 양호하나 일부 요약본 부재 } \\
\text { 및 목차 부적합 }\end{array}$ & $\begin{array}{l}\text { - 요약본 필수 작성 및 약어표기, 표· 차트 } \\
\text { 활용 등을 통해 가독성 } \cdot \text { 이해도 제고 필요 }\end{array}$ \\
\hline
\end{tabular}


〈표 3〉메타평가 보고서 등급화

\begin{tabular}{|c|c|c|c|c|}
\hline 점수 & 평가보고서 & 발주기관 & 평가 수행기관 & 등급 \\
\hline $\begin{array}{c}80 \text { 점대 } \\
\text { 이상 }\end{array}$ & 과테말라 난민정착지원 및 교육강화사업 2) & KOICA & $\begin{array}{l}\text { 글로벌발전 } \\
\text { 연구원 }\end{array}$ & 탁월 \\
\hline $\begin{array}{l}\text { 70점대 } \\
\text { 이상 }\end{array}$ & - & - & & 우수 \\
\hline \multirow{9}{*}{ 60점대 } & $\begin{array}{l}\mathrm{KOICA} \text {-농식품부 캄보디아 농촌분야 } \\
\text { 사업공동평가보고서 }\end{array}$ & $\begin{array}{l}\text { KOICA } \\
\text { /농식품부 }\end{array}$ & $\begin{array}{l}\text { 한국농촌 } \\
\text { 발전연구원 }\end{array}$ & \multirow{9}{*}{ 양호 } \\
\hline & ICT 훈련센터 건립사업 & KOICA & $\begin{array}{l}\text { 대한정보 } \\
\text { 기술(합) }\end{array}$ & \\
\hline & 라오스 모자보건 증진사업 & 보건복지부 & 서울대 의학연구원 & \\
\hline & 베트남 국별평가 & EDCF & $\begin{array}{l}\text { 대외경제정책연구원 } \\
\text { /수자원공사 }\end{array}$ & \\
\hline & 캄보디아 국가측량기준점 설치사업 & KOICA & $\begin{array}{l}\text { 한국지리 } \\
\text { 정보학회 }\end{array}$ & \\
\hline & 우즈베키스탄 국별평가 & KOICA & 산업연구원 & \\
\hline & 한베산업기술학교 2차지원사업 & KOICA & $\begin{array}{l}\text { 국민대 국정관리 } \\
\text { 전략연구소 }\end{array}$ & \\
\hline & 2011년도 무상원조사업 수원국 만족도 조사 & KOICA & $\begin{array}{l}\text { 성균관대 } \\
\text { 산학협력단 }\end{array}$ & \\
\hline & 에티오피아 아르시존 사업평가 & KOICA & 내부 & \\
\hline \multirow[t]{2}{*}{ 50점대 } & 인도네시아 병원폐수 처리시설 확충사업 & EDCF & $\begin{array}{l}\text { 한국개발 } \\
\text { 전략연구소 }\end{array}$ & \multirow[t]{2}{*}{ 보통 } \\
\hline & 중국 흑룡강성 모단성-계서간 도로건설사업 & EDCF & 내부 & \\
\hline \multirow{5}{*}{ 40점대 } & $\mathrm{NGO}$ 지원사업 종합평가 & KOICA & 경희대 NGO대학원 & \multirow{5}{*}{ 미흡 } \\
\hline & 상하수도 분야평가 & EDCF & 수자원공사 & \\
\hline & 국제빈곤퇴치기여금 사업 & KOICA & 고려대 산합협력단 & \\
\hline & 해외방송통신전문가 초청연수 & $\begin{array}{l}\text { 방송통신 } \\
\text { 위원회 }\end{array}$ & $\begin{array}{l}\text { 대한정보 } \\
\text { 기술(합) }\end{array}$ & \\
\hline & 정부초청 장학생 사업 성과분석 및 평가 & $\begin{array}{l}\text { 교육과학 } \\
\text { 기술부 }\end{array}$ & 연세대 & \\
\hline
\end{tabular}

2) 메타평가 수행자별로 평가 기준 적용의 엄격성이 완전히 일치하기는 어려우므로, 동 평가대상의 점수 격차는 일정부분 평가자의 관대성에 영향을 받았을 가능성이 있음. 


\section{(자체평가 보고서의 품질 문제의 인식 및 개선방안 도출)}

17 개 표본 자체평가 보고서 중 보통 이하의 평가를 받아 개선이 필요한 평가보고서는 총 $42 \%$ (7개)로, 이 중 미흡(40점대), 미달(30점대) 등급을 받은 보고서는 5 개에 달했다. 보고서 의 주요 항목별로 문제점을 살펴보자. 우선 평가 배경 및 목적이 비교적으로 명확하게 서술된 보고서도 있으나, 대부분은 일반적이거나 추상적으로 기술되어 있어 평가의도, 평가 대상 평 가 주사용처를 파악하기 어려웠다. 무엇보다 보고서상 프로젝트 기획 매트릭스(PDM: Project Design Matrix)에 대한 검토가 미흡했으며, 이는 사업기획단계부터 국제개발협력사업의 특성 에 따라 평가 설계가 포함되지 않은 문제점을 보여준다. 지표설계, 데이터 수집기술, 분석방법 등 평가방법론에 대한 상세하고 타당한 설명이 부족한 편이며, 방법론의 한계를 명시하여 해 석의 오류를 방지하는 노력도 미흡하였다. 통합평가지침에서 제시하고 있는 DAC 5 대 평가기 준에 대한 이해의 부족은 수원국 개발전략과의 구체적 연관성 분석, 목표달성 정도와 계획된 수혜자와 실제수혜자와의 동일 여부 분석 등이 미흡하며 정성적 평가에 국한되는 경향을 초래 했다. 또한 평가 결과의 신뢰도와 직결되는 자료의 수집방법에 대한 설명과 종합적인 분석을 가능하게 하는 평가지표와 측정방법간 논리구조 부족 및 일반적이거나 추상적인 제언 그리고 환류를 위한 실행가능한 구체 행동계획 미제시도 주요 문제점으로 지적되었다.

상기 문제점은 예산 및 인력 등 평가 인프라라는 근본적인 문제에도 연계되어 있지만, 동시 에 이 중 다수가 평가인식 및 역량과 관련된 문제라고 볼 수 있다. ODA 사업 계획 시 국제개 발협력 성격에 맞는 평가설계가 함께 이루어지는지, 평가의 기초자료인 사업 현지의 기초조사 (통계 등)가 실시되는지 그리고 평가기준에 대한 정확한 이해를 가지고 평가를 수행할 수 있는 지 등은 평가인식 및 역량 제고 노력을 통해서 개선이 가능하다. 이러한 점을 감안하여 금번 메타평가 결과보고서는 메타평가의 정기 시행과 더불어 평가소위가 ODA 수행기관들의 평가 역량 강화를 위해 노력할 것을 제언하였으며 평가소위원회는 이를 받아들여 평가 역량증진 워 크숍, 평가 보고서 가이드라인 마련 등을 2013년 평가소위 계획에 포함시켰다.

이렇듯 금번 메타평가는 기존 통합평가제도를 내실화하고 한 단계 더 발전시키는 계기를 제 공하였다. 통합평가제도가 실질적인 효과를 가질 수 있도록, 우리나라가 지향하고 있는 "개발 효과성”을 도출할 수 있는 원조사업을 만드는데 기여할 수 있도록 평가제도의 부족한 면을 보 완해 나가는 이러한 노력들이야 말로 머지않아 우리나라가 선진공여국으로 자리매김할 수 있 는 기반이다. 


\section{(KOICA, 평가 역랑 강화 및 선진화에 선도적인 역할 수행)}

금번 메타평가의 또다른 의의는 평가 분야에서의 KOICA의 역할을 다시금 주목하게 된 것 이다. 메타평가 결과보고서에 따르면, $\mathrm{KOICA}$ 의 평가보고서들은 여타 기관들에 비하여 높은 수준을 보여주었다. 양호(60점대)에 해당하는 10 개의 보고서 중 6 개가 KOICA의 보고서였으 며, 가장 최상의 평가를 받은 것도 $\mathrm{KOICA}$ 의 '과테말라 난민정착 지원 및 교육강화 사업 평가 보고서'였다. 이는 놀라운 일이 아니다. 사실 높은 수준의 평가의 질(quality)은 평가인식, 역 량 및 인프라와 비례하기 때문이다. KOICA가 원조전담기관으로서 평가 정책, 독립성, 자원, 계획, 확산 및 환류에 거친 전반적인 평가 시스템이 체계적으로 갖추어져 있기에 가능한 것이 라고 볼 수 있다. 물론 평가시스템 강화를 위해 노력해 온 $\mathrm{KOICA}$ 의 노력은 이와 별개로 높이 평가되어야 마땅하다. 특히 또 다른 원조전담기관인 $\mathrm{EDCF}$ 에 비해서도 평가품질이 높은 점은 $\mathrm{KOICA}$ 의 원조평가 분야에 있어서의 독보적인 지위를 보여준다. 그러나 금번 메타평가 결과 차원에서 $\mathrm{KOICA}$ 의 평가보고서가 높은 등급을 받았다는 사실 자체는 그리 중요하지 않다.

오히려 우리가 주목해야하는 보고서는 $\mathrm{KOICA}$ 와 농림수산식품부가 공동으로 참여한 '캄보 디아 농촌분야사업 공동평가보고서'이다. 표3에서 보듯 동 평가보고서는 거의 우수등급에 근 접한 평가를 받았다. 메타평가 결과 보고서도 $\mathrm{KOICA}$ 와 부처간에 실시된 공동평가는 전반적으 로 품질이 우수하다고 명시하면서. 농림수산식품부가 자체적으로만 실시한 국제농업협력사업 의 평가보고서는 평가점수가 저조했다는 점을 언급하고, 전자의 경우 공동평가이기에 높은 점 수가 가능했다고 분석하고 있다.

이렇듯 $\mathrm{KOICA}$ 는 현재 미흡한 수준에 머무르고 있는 여타 기관의 평가 역량 향상에 긍정적 인 영향을 미치면서 우리나라 개발협력 평가의 선진화를 선도할 수 있다. KOICA 평가실에서 발간하고 있는 각종 평가 관련 자료와 지침들은 20 년 남짓 원조전담기관으로서의 경험과 전문 지식을 바탕으로 마련된 것으로 전정부적인 평가 역량 강화를 위해 활용될 필요가 있으며, $\mathrm{KOICA}$ 와 여타 시행기관의 공동평가는 시행기관에게 국제개발협력 평가지식의 공유의 기회를 제공할 수 있다는 점에서 의미가 있다.

또한 금번 메타평가 실시에 있어서 $\mathrm{KOICA}$ 의 기여는 상당한 편이다. 처음으로 실시되는 메 타평가이었기 때문에 메타평가에 대한 정확한 이해를 바탕으로 한 분석과 제언이 필요했으며, 이러한 까닭으로 $\mathrm{KDS}$ 는 동 용역을 수행하는 과정에서 $\mathrm{KOICA}$ 평가실과 지속적인 협의를 실 시하였다. 이러한 점을 모두 고려할 때 금번 메타평가의 의의는 KOICA가 보유한 평가전문성 
에 대한 재확인이자 전정부적인 평가역량 강화를 위한 $\mathrm{KOICA}$ 의 선도적 역할 필요성이라고 여 겨진다. 물론 이러한 점은 여타 원조시행기관과의 관계에서 발생하는 상대적인 것으로, 원조 전담기관으로서 $\mathrm{KOICA}$ 역시 보다 정교한 평가체계와 보다 더 높은 평가전문성을 위해 더 노 력할 필요가 있다.

\section{4. 향후 효과적인 메타평가 추진을 위한 제언}

\section{메타평가를 비난이 아닌 독려를 위한 장치로 활용해야...}

2012년 말 제11차 평가소위원회에 상정할 메타평가 결과 안건을 작성하는 과정에서 자체평 가 결과가 미흡하게 나온 시행기관들은 메타평가 보고서의 점수화에 대해 상당한 우려를 표명 한 바 있다. 결국 안건을 보면 2010년 및 2011년 메타평가 대상인 자체평가 보고서의 평가결 과표는 우수 보고서와 개선필요 보고서로만 분류하고 각 보고서별 메타평가 상세 점수는 표시 하지 않았다. 이러한 시행기관들의 우려와 반응은 메타평가에 대한 '오해'에 따른 것이라고 본 다. 메타평가는 사업 시행기관을 '비난’하기 위한 장치가 아니다. 오히려 보다 나은 평가를 하 도록 '독려'하기 위한 장치라고 보아야한다. 무엇보다 메타평가는 시행기관의 사업 자체에 대 한 평가가 아니며, 시행기관이 수행한 사업을 평가한 외부 평가용역기관(자체평가는 대부분 외부평가 또는 공동평가로 진행)에 대한 평가이기 때문이다. ODA 사업시행기관은 메타평가를 통해 어느 평가용역기관이 국제개발협력 사업 및 평가에 대한 전문성이 큰 지를 비교하고, 역 량이 더 좋은 평가용역기관에 대한 정보를 얻을 수 있으며, 평가용역기관 간 선의의 경쟁을 촉 진할 수 있는 기제로 활용할 수 있다. 물론 시행기관이 자체평가를 책임진다는 점에서 메타평 가 결과가 부담스럽게 작용할 수는 있겠지만, 그 부담이 오히려 해당기관차원에서 평가에 대 해 더욱 큰 관심을 가지고 강화하는 유인으로 작용하게 되는 효과가 있다는 점을 간과해서는 안된다. 메타평가는 근본적으로 품질이 좋은 평가를 독려하기 위한 것이며, 상대적인 평가결 과를 통해 기관들은 보다 나은 평가를 위해 더 노력할 수 있는 유인을 갖출 수 있다. 


\section{평가사례 공유를 통해 메타평가를 평가 역량 강화를 가능하게 하는 지식공유 활동으로 추진해야...}

메타평가가 평가 품질제고를 위한 유인체계가 되기 위해서는 평가의 좋은 사례와 나쁜 사례 를 구체적으로 보여줄 수 있어야 한다. 평가 기준에 대한 정확한 이해를 보여주고, 어떤 평가 지표를 가지고 어떻게 분석을 해야하는지 등에 대한 사례를 공유하는 것이야말로, 현재 평가 역량이 부족한 많은 기관들에게 좋은 참고자료가 될 수 있으며 원조전담기관을 제외하고는 평 가역량이 높지 않은 우리의 현 상황에 있어서 가장 필요한 메타평가의 의의라고 할 수 있다. 금번에 시범적으로 추진된 메타평가 결과보고서('2010년-2011년 자체평가 품질에 대한 메타 평가'제하의 용역보고서(2011.11월 발간)')는 아래와 같이 개선이 필요한 예와 잘된 예를 평가 사례에 기반하여 보여줌으로써 평가 수행 시의 잘못된 이해 또는 실수를 방지할 수 있도록 정 보를 제공하고 있다.

\section{〈표 3: 영향력 평가 사례〉}

※ 영향력 분석의 예시

(개선이 필요한 예)

$\square$ 사업으로 인한 계획된 변화와 영향

“흑룡강성 모단성 계서간 도로건설사업”의 평가매트릭스 상에서는 영향력 평가지표로 빈곤 감축 및 제도, 사회경제, 환경에 미친 영향력, 수혜자평가(사업의 직간접적 수혜자들이 동 사 업의 영향에 대해 평가하는 정도)등이 제시되어 있으나. 실제 평가에서는 GRP(Gross Regional Product), GDP, 취업자 수, 관광산업 관련 지표 변화를 평가함. 아울러 제시된 데이터는 도 로건설사업에서 기인한 것이라고 확신하기에는 논리적인 비약이 있음

“해외방송통신전문가 초청연수”의 영향력 평가항목에는 연수에서의 학습결과가 수원국 국가 정책에 반영되거나 이로 인한 제도적 변화 가능성이 있는지를 평가해야한다고 명시하고 있 으나, 실제 평가는 한국 및 ICT 분야 이미지 개선효과 등을 중심으로 하고 있음. '연수사업결 과 해당 수원국에서 긍정적 변화가 있었는지'의 평가문항은 너무 포괄적이므로 구체화할 필 요가 있음

(잘된 예)

$\square$ 사업으로 인한 계획된 변화와 영향

“과테말라 난민정착지원 및 교육강화사업”은 PDM에 기반하여 효과성 연장선상에서 지원 사 업을 통해 주민들의 사회·경제적 환경이 개선되었는지를 간접적으로 평가하였음. 영향력 평 가지표로 중등학교 시설 설립 후 마을 전반에서 중학교 교육을 받을 수 있는 학생수 증가, 생산기반 시설 구축과 생산투입 자재 제공 등으로 마을 소득 증대에 기여, 사업 과정에서 주 민조직의 적극적 참여 도모로 주민조직 역량강화에의 기여를 분석하였고, 그 결과 긍정적 영 향이 있었다고 평가함 
금번 메타평가에서 도출된 사례들은 평가소위원회 차원에서 또는 평가 협조기관차원에서 별도 사례집으로 만들어 원조 시행기관들에게 참고자료로 배포하는 것도 고려해 볼 만하다.

\section{자체평가 확대 노력과 연계...}

금번 메타평가 결과보고서에서 언급되었듯이, 자체평가 보고서를 공개하지 않거나(기획재 정부의 $\mathrm{KSP}$ 사업), 만족도 수준의 조사에 한정되어 평가라고 보기 어렵거나(여성부), 평가를 아예 실시하지 않는(지식경제부) ODA 시행기관들의 자체평가가 원활히 이루어질 수 있도록 자체평가 확대 노력을 병행해야 한다. 향후 메타평가 결과 공유 및 평가보고서 가이드라인 마 련 등은 현실적인 제약으로 자체평가 추진에 소극적이었던 기관들을 변화시킬 수 있을 것으로 예상된다.

\section{평가소위원회, 메타평가 이행을 통해 주도적인 역할을 수행해야...}

그간 평가소위원회는 평가계획 수립, 평가 실시 및 평가 결과 심의 및 국제개발협력위원회 앞 보고 역할을 수행해 왔으나, 평가 실시 및 결과 심의에 있어서 주도적이며 적극적인 역할을 수행해왔다고 보기 어렵다. 소위평가의 경우 간사기관인 국무총리실이 외부 용역 발주 형태로 추진되어, 평가 실시에 위원들이 직접 참여하는 구조가 아니었으며, 평가 결과보고서도 평가 소위원들에게 1 주일 전에 배포되어 심도있는 검토가 곤란한 문제가 있었다. 평가소위원회의 역할 강화를 위한 제도적 개선 논의는 차후 위원회 차원에서 별도로 이루어질 것으로 보이나, 평가소위원들의 역할 강화와 관련하여 메타평가 측면에서도 고려해야할 점이 있다. 서두에서 언급한 바와 같이 지금과 같이 무상원조가 분절화된 상황에서는 예산 및 인원 등 현실적인 제 약을 고려할 때 원조 전담기관이 아닌 여타 무상원조 시행기관이 자체평가를 시행하면서 품질 관리까지 다루기는 매우 어려운 일이다. 이러한 차원에서 품질관리 유인체계를 마련하고 시행 기관의 평가역량 제고를 제도적으로 지원하는 메타평가야 말로 평가소위가 주도적으로 할 수 있으며, 해야만 하는 일이라고 여겨진다. 평가소위가 2 년 주기로 메타평가를 실시하기로 결정 한만큼, 평가소위 위원들이 직접 메타평가에 참여하여 주도할 수 있기를 기대한다. 평가소위 가 주도적 역할을 하기 위해서는 금번에 이루어진 시범 메타평가 결과에서 제시된 메타평가 분석틀과 체크리스트를 참고하여, 평가소위 위원들이 직접 관여하여 메타평가 세부가이드라인 을 구축해야 한다. 


\section{외교통상부, KOICA의 무상원조 평가역량 고도화 및 여타 시행기관들의 역량 강화 지 원을 통해 개발효과성 제고를 위해 노력해야...}

무상원조 정책을 총괄하는 외교통상부는 우리 정부가 지향하는 개발효과성을 제고하기 위 해 평가에 보다 많은 자원을 투자하고, 무상원조 평가 기능을 강화하는데 더욱 힘써야 할 필요 가 있다. 평가의 품질은 결국 정책의 품질로 귀결되기 때문이며, 이는 국제사회에서 선진공여 국으로 활동하기 위한 필수적인 기반인 까닭이다.

이러한 차원에서 전체 무상원조의 $80 \%$ 를 수행하고 있는 $\mathrm{KOICA}$ 의 평가역량 고도화 작업을 적극 추진하여 $\mathrm{KOICA}$ 의 평가분야의 선도적 역할을 지속 확대해 나가야한다. 또한 여타 선진 공여국 및 국제기구와 평가 선진화에 대한 논의를 지속하여 평가분야의 전문성을 강화해 나가 는 노력을 전개하는 동시에, 이를 바탕으로 여타 시행기관들의 사업평가를 지원함으로써 다양 한 원조사업들이 개발효과성을 도출하는 방향으로 개선될 수 있도록 노력해야 한다. 이러한 노력이 평가소위원회의 메타평가와 함께 추진될 때, 메타평가의 '자체평가 품질관리'의 목적이 달성될 수 있다. 결국 메타평가 결과에 따른 원조 시행기관의 평가 개선 및 역량 강화는 외교 통상부가 원조전담기관인 $\mathrm{KOICA}$ 와 함께 얼마나 적극적으로 이를 지원하고 선도하는가에 달 려있는바 향후 외교부와 $\mathrm{KOICA}$ 의 국제개발협력 평가분야에서의 적극적인 역할을 기대한다. 


\section{참고문헌}

국제개발협력기본법

국제개발협력위원회 (2010) 국제개발협력 평가소위원회 운영규정 및 평가지침

국제개발협력위원회 (2010) 국제개발협력 통합평가계획 (제7차 국제개발협력위원회 안건)

국제개발협력 평가소위원회 (2012) 제 11 차 평가소위원회 안건 : ODA 시행기관의 자체평가에 대한 메타평가 결과

한국개발전략연구소 (2012) 2010년-2011년 자체평가 품질에 대한 메타평가' 용역보고서 